\title{
日本照明委員會 活動寫眞照明委員會報告
}

\author{
活動寫呂照明委員會委員長 氏 原 佐 藏
}

The Report of the Committee on Cinema Lighting. (The Japanese Committee on Illumination)

By Sazo Ujihara, Chairman.

目次

\begin{tabular}{|c|c|c|c|}
\hline \multicolumn{4}{|l|}{ 序 } \\
\hline 祀 & & 事 & \\
\hline I & 組 & & 織 \\
\hline II & 會 & & 合 \\
\hline III & 報 & 告 & 書 \\
\hline
\end{tabular}

序

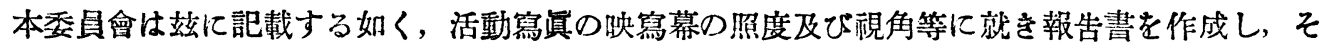
の英譯を本年九月フメリカ合臬國に於て開催せらる」萬國照明委員會大會に提出せり。依て茲に その經渦及び報告書，參考資料等を一括して第一四の報告青とせり。沿本件に關しては，萬國照 明委員會の決議に基を，我が日本國が之が調查研究の引受國たる關係上，對外的にも對內的にも 更て調查研究を繼續すべをものとす。

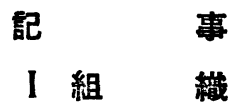

委員長

內務省筒生局

內降技師争商工技師 醫學博士 氏原 佐藏

主 查

東京電策株式會社

理學士 猪狩 滿和

東京電氣株式會社

河野 元站

委 員

坂本製作所

工學士 原 愛次䬦

復興局建策部

東京帝國大學醫學部眼科敉室

海軍省人事局

陸军省新聞社

京都高等工藝學校

文部省普通學務局

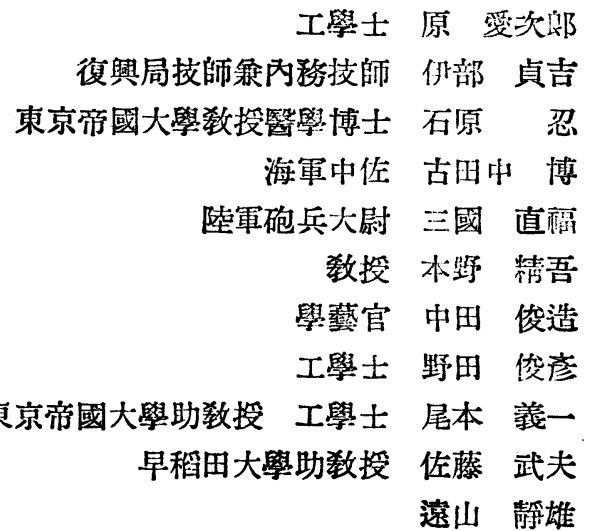

警視魷建築課

東京帝國大學工學部電氣工學教室 早稻田大學理工學部建築科敉室

逗山 静雄 
東京電氣株式會社

內務省警保局
日本照明委員會理事 內坂 素夫

法學士 楖井 義男

\section{II 會合}

\section{(I) 委員會}

第一回

日 時 昭和二年十一月二十四日(木)午後五時より

出席者 (委員長) 氏原佐藏君 委員 原愛炏郎君 同 猪狩滿和君 同 河野元君君 同 古田中博君 同 野田俊堂君 同 遠山静雄君 同 內坂素夫君

記事

開會汇先ち, 內坂日本照明委員會理事上り, 日本照明委員會，萬國照明委員會及び本委員會開 催汇關する說明及び换掺あり。併せて將來の希望を述へらる。

1. 委員會名並!調查研究篹園

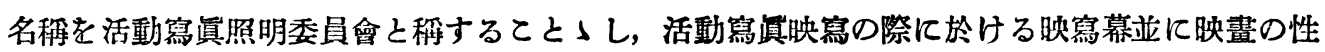
質より照明の全般に及ふすのとす。

2. 第一次調查研究項目

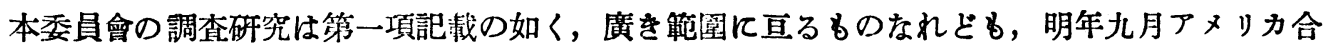
臬國に開かる〉萬國照明委員會に提出する報告書を作成する必要より, 先つ次の項目に從ひ研究 するととなす。
(1) 映寫幕の輝度
（2）照明之疲勞
(3) 頑 角
(4) 投射角
（5）咉寫幕の材料之梇造
（6） 觀筧室の照明
(7) 仕樣書
(8) 資 料
(9) 交 献

\section{3. 調查研究方法}

第二項の研究項目に從ひ，照明，物理，衞生，視力の關係，映寫の實祭等の各方面上り調查す るととなす。

\section{4. 委員}

本委員會委貝は組織欄記載つ通りにして，委員長及び主查を互選す。

第二回

日 時 昭和二年十二月十三日(火)午後五時より

出店者 氏原委員長 猪狩, 河野兩主查 原, 伊部, 石原, 古田中, 三國, 中田, 野田 遠山 內坂各委員

記事

1. 猪狩主查上り事務報告

2. 㔫原委員長，河野主查，野时委員，遠山委員上り夫《資料の提出 
3. 各自分擔の資料を十二月末日までに照明學會事務所宛に送附するとと

4. 將來はデーライト・スクリーン, 發聲咉畫の研究をもなしたをてと

\section{第三包}

日 時 昭和二年十二月二十三日(金)午後二㭙上り（川崎市，東京電氣株式會社，照朋 學校に於て)

出席者 氏原委員長, 猪狩, 河野丽主查, 伊部, 石原, 古田中，三國，中田，野田，尾 本, 佐藤, 遠山, 內坂各委員

記 事

1. 氏原委員長より資料提出

2. 河野主查提出の各種咉寫幕材料の配光にて就て說明

3. 照明學校映寫室に於て活動寫真に關する各種の望驗をなす

第 四回

日 時 昭和三年一日二十七日(金) 千後五時より(歌舞伎座に於て)

虻席者 猪狩, 河野兩主查, 伊部, 石原, 三國, 中田, 野田, 尾本, 佐藤, 遠山, 內坂 各委員

記事

本委員會の目的と關係ある活動寫買胦寫の際に於ける各種の事項に就を賽地見學をなす。

第五间

日 時 昭和三年一月三十・日(月)午後五時より

出席者 氏原委員長, 猪狩, 河野兩主查, 石原, 伊部, 古田中, 三國, 尾本, 佐藤 遠山, 內坂各委員

記 事

1. 猪狩主查より事務報告

2. 今秋の萬國照明委員會大會に提出すべき本委員會報告の內容に就ては, 大體最初に 定めたる項目に依ることつし，主查に於て適當に原案作成の上，次包會合までに各委員の手許に 送附するてと

3. 各委員より提出の調查資料は，次回會合までに事務所又は主査へ送附のてと

第 六间

日 時 昭和三年五月八日 (火) 午後五時より

出席者 氏原委員長, 猪狩, 河野爾主圭 伊部, 石原, 古田中, 野田, 佐藤, 遠山, 內 坂各委員, 田中 寬君

本日は特に昨年ベラヂオに於ける莴國照明委員會大會に出席せられたる田中寬君の御出席を乞 ひ, 大會の狀況につを御報告を願ひたり。

訅事

1. 田中寬君はべラヂオに於ける萬國照明委員會大會概況を報告せられ, 且つ今年の大 
會出席者に對する希然を萿べらる。

てれに對し內坂理事は唯今人選中なれば，御希望に添ふ樣盡力すべを旨の御話あり。

2. 猪狩主查より事務報告

3. 遠山委員より邦樂座招待券の寄贈

4. 河野主查，佐藤委員上り實驗資料の提出並に說明

5. 猪狩主查報告書原案の說明

6. 報告書原案作成のため, 遠山, 佐藤, 猪狩, 河野四君は小委員會を開くこと 第七回

日 時 昭和三年六月二十五日（月）午後五時より

出席者 氏原委員長, 猪狩, 河野兩主查, 原, 石原, 尾本, 佐藤, 遽山, 內坂各委員, 小西彥鹰君

記事

1. 內坂理專上り東京電氣株式會社の小西彥君君代表委員として萬國照明委員會大會に 出席せらるよことよなりたる旨の挨拶あり。

2. 猪狩主查上り事務報告

4. 猪狩主查より報告書原案につ說朋

報告書の詳細なる訂正に對しては，小委員會に一任するてとに汽定し，本日を以て提出報告書 の質疑を終了す。

(II） 小委員會

昭和三年五月十六日（水）正午上り第一回 昭和三年五月二十六日（土）正年年より第二包 昭和三年六月二十五日 (月) 午後三時上り第三包開催

出席者 猪狩, 河野雨主查 佐藤, 遠山各委員 內坂理事小西彥鹰君 萬國照明委員會大會へ提出する報告書原案につを委員間つ打合せをなす。

(III） 各部門聯合打合會

日本照朋委員會より今秋アメリカ合衆國に於て開催せらる〉萬國照明委員會大會に提出する, 活動寫真照明, 自動車前照燈, 信號燈, 街路照明, 學校照明, 及び山內氏諭文につき代表出席委 員本野照明學會長と各報告書記草者との打合せを, 昭和三年六年二十日（水）午後五時より及び 同年七年十八日(水)正乎よりの二回開催せられ，本委員會上りは猪狩，河野兩主查出席して說明 の任に當れり。

\section{III 報 告 墨}

上記の組織の下に調查研究したる結果に基き，主査に於て報告書原案を起草し，前記の通り委 員會に於て討議訂正して委員會報告書を作成せり。てれを英文几䧽譯したるるのに，佐藤委員の 映畫の歪に關する論文の英臎を附錄として本年九月アメリカ合衆國に於て開催せらる」萬國照明 委員會大會に提出せり。 


\section{活 動 寫 畺 照明}

\section{映寫幕の輝度及び視角に關する報告}

活動寫滇映畫は，一般に靜止映畫に比して眼の疲勞を來すてと荙だしきものなり。近來活動寫 直の發達に伴ひ，或は常設館に，或は臨時の會場に，その映寫せらるつこと益く多をを加ふるに

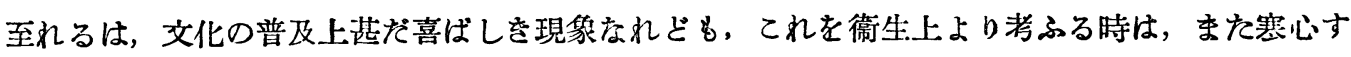
べきものなをにしもあらず。この時に當り 1927 年 9 月イタリー國ベラヂオに開かれたる萬國 照明委員會大會は，その將來の事業として各種の問題を萬國協同して研究するてとを決議し，そ の中に活動寫㛲に關する研究をも加へたるは，誠に時宜を得をるるのといふべし。而して我が日 本照明委員會はこの活動寫真照明を分擔するてとつなれり。郎ち本委員會は日本照明委員會の一 委員會として, 萬國照明委員會の決議に基づき活動寫真照明, 主として先づ映寫幕の輝度, 視角 等につを調査することつし，或は研究に，或は實地測定に，前後九回の會合を開をたる上，調查 したる結果を兹て報告す。

昭和三年七月

\begin{tabular}{|c|c|c|c|c|c|c|c|c|c|c|}
\hline 本照萔委 & & 活動苩 & 曋照 & 腇員會 & & & & & & \\
\hline 委員長 & 氏 & 原 & 佐 & 藏 & 委 & 員 & 本 & 野 & 精 & 吾 \\
\hline 主 查 & 猪 & 狩 & 滿 & 和 & 同 & & 中 & 田 & 俊 & 造 \\
\hline 同 & 河 & 野 & 元 & 彥 & 同 & & 野 & 田 & 俊 & 彥 \\
\hline 委 員 & 原 & 愛 & 次 & 郎 & 同 & & 尾 & 本 & 義 & 一 \\
\hline 同 & 伊 & 部 & 貞 & 吉 & 问 & & 佐 & 藤 & 武 & 夫 \\
\hline 同 & 石 & 原 & & 忍 & 同 & & 裳 & 山 & 靜 & 雄 \\
\hline 同 & 古 & 田 中 & & 博 & 同 & & 內 & 坂 & 素 & 夫 \\
\hline 同 & 三 & 國 & 直 & 福 & 同 & & 柳 & 井 & 義 & 男 \\
\hline
\end{tabular}

\section{序 言}

活動寫貢の映寫に際しては，その常設館たると又臨時の會場たるとを問はず，本推獎標準に從 て諸種の設備を整ふるととを勸む。

\section{第一節 映寫幕に於ける照度}

映畫面つ明るさは，何れの座席よりするも困難を感ぜずして映畫を見得る程度たるへく，フイ ルムを挿まざる時の平均の照度は 25 メートル燭を下らざるてとを要す。

\section{第二節 仰 角}

觀客の眼と映畫の中心とを結び付くる直線が水本面となす角は $25^{\circ}$ を超ゆべからず（㙷に眼の 
高さは床面上 100 センチメートと假定す)。

第三節 横 角

映熭の中心を含み，てれに垂直なる鉛直面と，観客の眼及び映畫の中心を含む鉛直面とのなす 角は $45^{\circ}$ を超ゆべからず。

第四節 投射角

投射レンズの中心と映畫の中心とを結び付くる直線が水平面となす角は $20^{\circ}$ を超ゆべからす。

\section{第五節 映寫幕に最も近き座席}

映畫の山心を通る映寫幕上の水平線を含む鉛直面より，映畫の幅の 1.5 倍の距離に於て之と平 行する鉛直面以內に座席を設くぐからす。

\section{第六節 映寫慕より最も遠き座席}

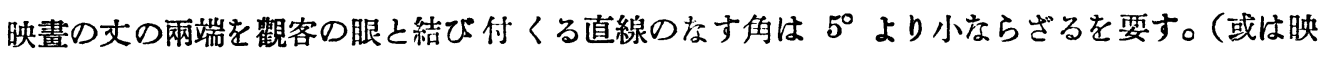
寫幕つ中心より最も遠を座席の距離は, 映畫の丈の 12 倍を超ゆべからず。)

\section{第七節 眼の疲勞と保護}

本推獎標準はすべて眼の保護を目的とせるものなれども，前數節に述べをるもの以外に重要な るものを弦に記載す。

甚だしく損傷して非常にちらつをを生ずをフィルムを使用するでからず。長時間の映寫に際 しては途中に休秝時間を設け，連續映寫時間は 2 時間を超ゆることなく，全映寫時間はむ時間以 上に亘らさる要す。

\section{第八節 映寫慕の材料並びに構造}

映寫幕の材料は投射せられたる光をなるへくく觀覽席の全面に向て反射し，すべての座席より容 易に映畫を見得る如をるのを用ふるを可とす。その取り附け方は, 映寫機の位置と座席の配置之 を考虑して映畫を見易くする樣に努むべし。室內に於ては勿論，野外等に於ても幕の動搂せさ る樣注意すへし。

\section{第九䉇 觀覽室の照明}

觀覽室には映寫中之踓も觀客の容貌を認識し得べを照度を有する燈火の設借をなし，觀客の使 用し又は來往する各場所には充分なる照度を有する電燈刃は他の安全なる燈火の設供をなすは必 要なることなれども，映寫せんとするに當りては，燈火を急に消すてとなく次第にてれを暗くし て逐に消燈するが如を方法を用ひ，又映寫を終へたる時は同樣の手没によりて點燈し，映寫の前

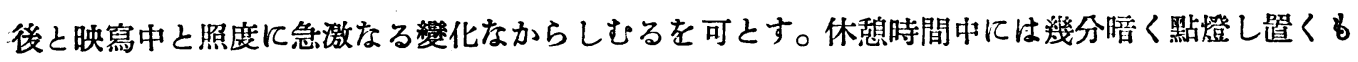
亦一案なり。又映寫中に觀覽室を出入する場合, 室外之室內と急激なる照度の變化なからしむる 樣, 室外の照度より室內の照度まで，次第に變化せる照度の廊下を設くるてとを勸む。

\section{第 二 章 推獎標準決定に關する說明}

活動寫面照明に關する標準を定むるには，或は理論より研究し，或は實驗によりてその效果を 捡證する必要あるへし。邓他面より考ふる時は, 生理學, 心理學, 物理學, 建築學等の廣汎なる 
科學に關係するものなれば，是等關係諸科學の各方面より考究せざるでからず。第一章に制定せ る推獎栖淮は委員各自の專問的立場より既往の知識と實驗とに基づき夫そ調查研究せる結果を綜 合せるものなり。而して本章に於ては何故にかく定めたるか, その理由或は出處を說明し侧か參 考化資呋んとす。

\section{第一節 映寫幕に於ける照度に就て}

映畫觀覽の際, 畫像不明蹽なる時は徒に眼の疲勞を來たし, 觀覽者をして不快を感ぜしめ, 視 覺を害するが如をとてなをを保し難し。映畫の明暸なると否とは，明暗の對比と全體としての平 均辉度とによるへく，平均輝度高く且つ對比大なる時は映畫明睹なるへし。但し對比大なるをよ しとすれども矓帮を感ぜさる程度なるを要す。茲に平均辉度といひ或は或は對比といるも, 實際 の出畫に接しては皆夫く特有なる輝度と對比を有すべく, しかもてれするによりてその映畫の價 值を高むる場合もあるへく，概括的にその輝度を幾何とし，又對比を如何にすべしと規定するが 如きは，乏しき資料にては蓋し至難のてとに䐂す。よりて茲には單に大體の方針を示しフイイ ムを插むさる時の幕面の本均照度の最小限度を舉ぐるてと১し, その值を如何に決定すべをかに 就ては實際の值を参考となすために，東京市內に於ける一二の活動寫真館にて幕面の照度を算测

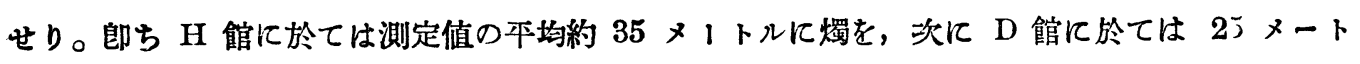
ル燭を得たり。

この實测の結果よりフイルムを挿入せさる時の幕面の本均の照度は 25 メートル燭以上となす べをてとを規定せり。蓋し $\mathrm{H}$ 館は東京に於ても照度最も高を方に屬し, 刃 D 館も普通よりは 照度高き方なるも，妶には將來益々照度の高まり行くことを希望する意味に於て 25 メートル燭 を探れるるのなり。

猶映寫中次第に照度を減し逐にてれ以下にては最早映畫を明膫に觀學し得ず認めたる時に， フィルムを拢き去りその照度を測りたるに約 10 メートル蠋を得をり。郎ち映畫を明瞭に認め得

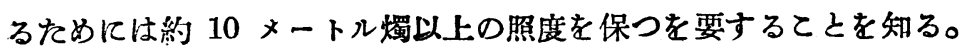

\section{第二節 仰角に就て}

座席を如何なる程度まで映寫幕に接近し得べをかに就ては，(1) 映畫を仰をて見るための疲勞 (1)（2）映畫の歪みて見ゆる事(2) の二點より考究せさるべからず。本節は主として仰き見るた めの疲勞より考ふるものにして, 最前列の座席餘りに映棉幕に近を時は觀覧者は非常に仰をて咉 畫を見るとと〉なる。眼を高所に向くる事は, 水平方向に向くことに比し, 眼の疲勞を來たし, 頭痛その他の不快を招くてと多し。不快を感するるは單に映寫幕が近をてと, 映畫の丈が高をてと のみによるるのにあらすして，更に重要なる映畫の中心が眼の水本面上冻何の高さにあるかとい ふ事なり。それ故に單に映寫幕よりの座席の最小距踓, 或は映畫の丈とその距離との比を指定す るのみにては不十分にして, 更に最前列座席つ觀覽者の眼より仰角を示すを要するなり。仰角を 表はすに，イギリスに於ては映畫の上緣の仰角を示しあれども(1)本標準に於てはすへてての場合に 映畫の中心を採りて考へ，映畫の中心の仰角は $25^{\circ}$ 以下なるべをとを規定せり。今映寫幕が鉛 直なる場合をとり映畫の中心と觀客の眼とを通る鉛直斷面を考ふ。郎ち第一圖に於て $A B$ を映畫 
とし， $O$ をその中心とす。而して $E$ を床面 $F F$ より 100 センチメートルの高さにある觀覽 者つ眼の位置とす。然る時は眼と映畫の中心と を結ひ付くる直線 $E O$ が水平面 $E H$ となす角 $\alpha$ は $25^{\circ}$ を超えさる㥞に映寫幕を設くべをてと を示すbのなり。イギリスに於ては映畫の上緣 の最大仰角を $35^{\circ}$ と規定す。(1)

本節は主として仰き見るための疲勞より考へ

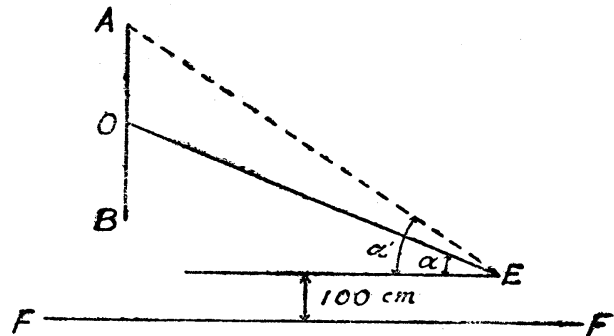

第 6 圖 たるものなれども，映畫の歪みの點より考ふる時は伏角にも制限の必要あるへし。伏角に就ては 次節横角之同樣最大角を $45^{\circ}$ と探りて可ならん。

\section{第三節 横角に就て}

映畫の仰角に關する條件滿足せられたる時，次に考ふべは觀覽室の兩側の壁に近き座席に於 は非常に拣の方向より映畫を見るために映畫が歪みて見ゆることなり。ての映畫が歪みて見ゆる ことは，仰角に對する疲勞よりはその程度著しからさるべきも，眼の痩勞を來す一原因となるべ ければ，茲に橫角の制限を設くるものなり。

今映畫を科に見る時の歪みに就て考ふるに，映寫幕の大さは，映寫幕と觀覽者との距離に街し て相當の大さを有するを以て, 映寫幕上の各部分に於ける相等しき長さが一般に等しく見えさる 事となる。簡單なる場合に就て丕みの如何なるものなるかを說明すべし。第二圖に於て $A B$ を 映畫面上の一つの直線とし， $C$ をその中點とすれば，觀覽者の眠 $S$ が $C$ を通り $A B$ に垂直なる本面上にある時のみ $A C$ と $B C$ とが 同じ長さに見え, $S$ がその平面より次第に離れ行くに從て $A C$ 之 $B C$ との比は次第に變化して見ゆぺし。 $S^{\prime}$ をかくの如き $S$ のつ の位置とし， $S^{\prime} C$ が $C$ を通り $A B$ に垂遖な平面となす角を $\theta$ とすれば， $S^{\prime}$ より見たる $A C$ と $B C$ との比は大略 $A^{\prime} C$ と $B^{\prime} C$ との比の如く見え, 元ヶ 1 の比なりしものが $\theta$ が大となるに從ひ 次第に 1 より遠ざかり行くへし。茲には任意の一つの直線に就て 考へたるものなれば, $A B$ の方面の如何に拘らす $\theta$ の值と $S^{\prime}$ D $C$ よりの距離とが一定ならば $A^{\prime} C: B^{\prime} C$ の比は一定なるへし。故に 映畫を科に見る時は，乙の上の直線は視線に對する夫たの方向の異 るに從て全體として異りたる長さに見ゆる外に，その直線自身の上 の各部分の比が異りて見ゆるてと」なる。而して全體としての長さ の絞化，及び一直線上の各部分の比は，眼より映畫上の注視點まで

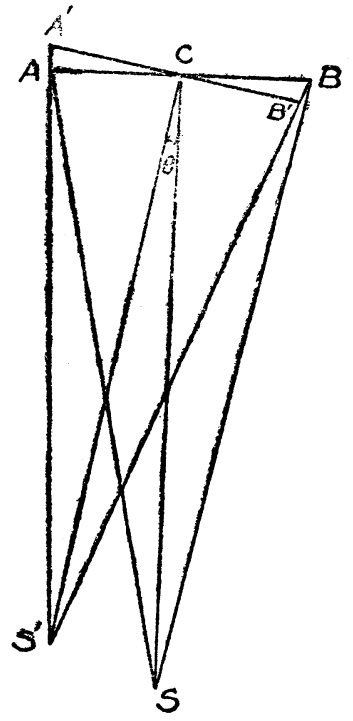

第 2 圆 の距離によりて變化するものなり。以上は單に 1 本の直線に就ての論なれども，實際の眏畫は面 積を有し，叉一般に上下と左右との相違あるへし，即ち例人ば人物等は一般に直立する場合多け れば自ら方向の差を注意する必あるが如し。故に映畫を斜に見る場合の歪みは，映畫に對しての 


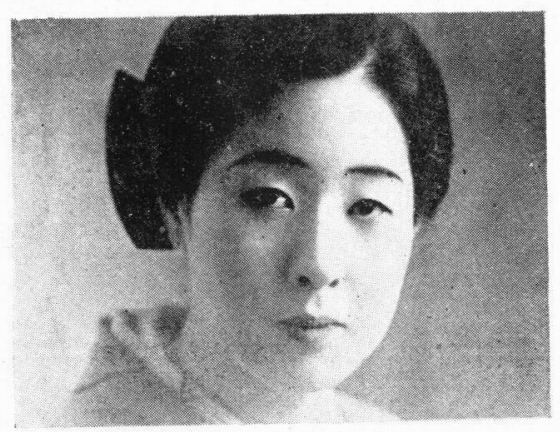

Harizontal Angle $0^{\circ}$

Vertical Angle

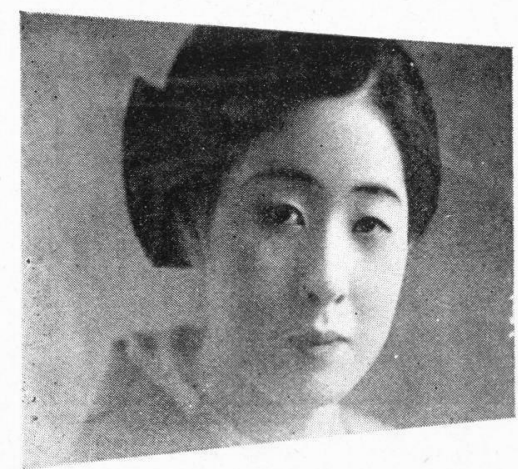

Horizontal Angle $25^{\circ}$

Vertical angle

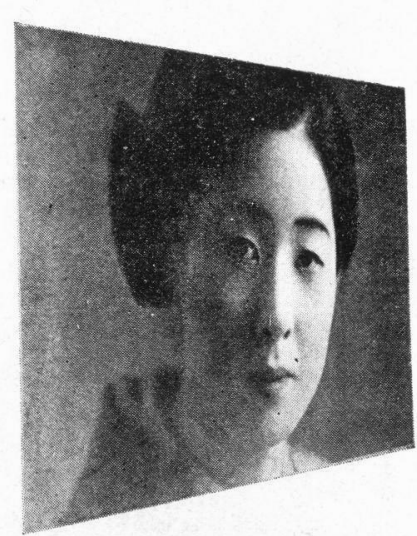

$\begin{array}{ll}\text { Horizontal Angle } & 45^{\circ} \\ \text { Vertical Angle } & 0^{\circ}\end{array}$

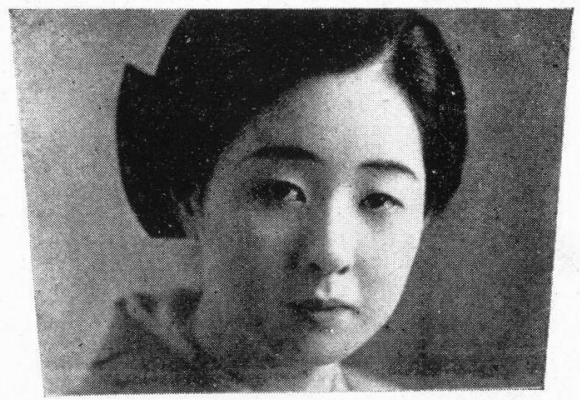

Horizontal Angle $0^{\circ}$

Vertical Angle $20^{\circ}$

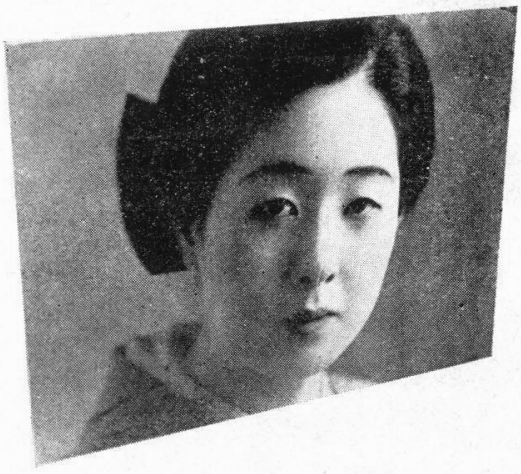

Horizontal Angle $25^{\circ}$

Vertical Angle $20^{\circ}$

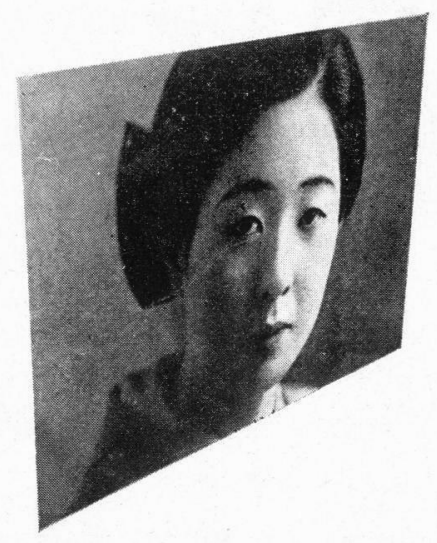

Horizontal Angle $45^{\circ}$

Vertical Angle $20^{\circ}$ 
水本角之鈆直角との組合せによるものとなり, 眼の位置の異るに從ひ, 全體の長さに變化を生 じ，且つ一直線上の各部分の比に變化を來し，更に二直線の夾む同一角度に變化を生ずるとと〉 なる。第三圖は映畫の歪みの一例を示すものにして, 同一繪畫を異りたる方向より見をる（實際 は寫萁に撮りをるすの) 場合に如何に見ゆるかを示するのなり。視角 $45^{\circ}$ 超ゆる時は外觀著し く異るを見る。てれによりてその限度は，映畫の中心に向ふ視線を含む鉛直面が映畫面に垂直な る鉛直面となす最大角を $45^{\circ}$ と規定せり。(2) 映寫幕が鉛直なる場合をとり，映畫の中心を通る水

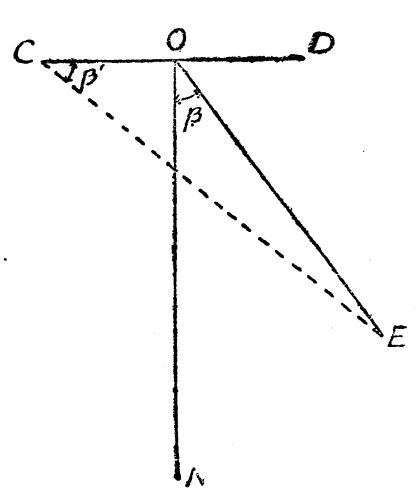

第 4 圆 本斷面を考ふ。即ち第四圖に於て, $O N$ を映畫の中心 $O$ を通り 映畫面に垂直なる鉛直面と水本面との交線とし, $O E$ を映畫の中 心に向方視線を含む鉛直面と水本面との交線とする時，角 $\boldsymbol{\beta}$ は $45^{\circ}$ より小なる樣座席を配置すべをものとす。イギリスに於て は映畫の中心を採らず, 觀覽者より遠を端を探り, 茲に示す $\beta$ 几相當する角の餘角 $\beta^{\prime}$ を採り $25^{\circ}$ と規定せり。(1)

茲に注意すべきととは, 映畫の歪みは單に $\theta$ が大となるに從 て例へば直線全線の長さが益々短かく見え， $A^{\prime} C: B^{\prime} C$ (第四圖) が益々變化するのみならす， $S^{\prime}$ のよりの距離によりてる $A$ $C: B^{\prime} C$ の比が變化することなり，即ち $S^{\prime}$ の距離大なる間は $S^{\prime}$ より $A C, B C$ までの距離の差は僅少なれども, 距離小となるに從ひてれ等の二つの距離の 差の割合は次第に大となり, $A B$ 全體として短かく見ゆる外に, $A^{\prime} C: B^{\prime} C$ の比が益ネ變りて見 之, 映畫面上の各部の面積が元と變りて見ゆるに至る。かくの如き點よりして座席の距離は或る 程度以上近くするてと能はざるぺし。座席の距離に就ては第五節に迅ぶ。

\section{第四節 投射角に就て}

映畫を拣に見る時に歪みを尘ずると同樣に，映寫幕に對して科に投射する時にも亦歪みを生す ベし(兩者の間には多少の相違あれども)。近來の大活動寫買館に於ては座席の關係 上映寫室は 高所に設けらる〉もの多をに至れり。映寫室を高所に設くる時は映寫幕の下部を映竄機の方に傾 けさる限り，映寫幕に對して科に投射せられ，映畫は歪みを來すへし。而して映寫幕を傾くる時 は下方の座席より見れば映畫は益く歪みて見ゆるを以て, 幕自身は自ら傾斜を制限せらるつてと \なれば，妶には單に投射角のみにつを記すてとなせり。而して最大投射角は或は $12^{\circ}$ (3) と， 或は $20^{\circ}$ (4) と規定せられあるる,茲には東京地方の活

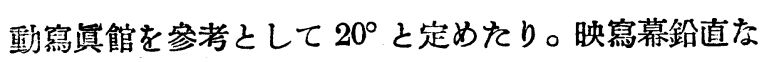
る場合を圖示せんに，第五圖に於て，ABを映畫とし， $O$ をその中心とすれば，投寫レンズの中心 $L$ と映畫 の中心 $O$ とを結び付くる直線 $O L$ が水平面 $O H$ と なす角 $\gamma$ は $20^{\circ}$ 以下なるを要するなり。

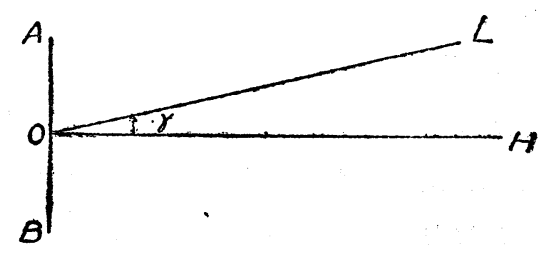

第 55 圆

投射角とは上下の傾をに就ての角なれども, 映畫に歪みを生ずるととは映寫幕と同一水本面上 に於て斜に投射する場合も同樣なり。若し映葟幕と同一水本面上に於て斜に投射する必要する場 
合に於ける角度の制限は，本文記載の角と同樣 $20^{\circ}$ を超えさるととを要す。

今試に東京地方に於ける三三の活動寫真館の投射角を舉ぐれば

$\begin{array}{lc}\text { 館 名 } & \text { 投 射 角 } \\ \text { 電 氣 館 } & 8^{\circ} \\ \text { 富 } & \text { 館 } \\ \text { 芝 園 館 } & 10^{\circ} \\ \text { 日 本 館 } & 17^{\circ} \\ \text { 邦 樂 座 } & 17^{\circ}\end{array}$

大體角度小なるもの多を樣なれども，亦大なるるのあれば，200をで吘容するてとよせり。

\section{第五節 映寫幕に最も近き座席に就て}

映寫幕に最も近を座席に就ては，仰角よりる制限を艾くるものなれども，映畫の歪みの點より 本節を設けたり。最前列の座席に關しては咉畫の左右兩端を眼に結び付くる二つの直線のなす角 が50゚を超えざることによりて規定せられある場合もあり。茲にはその映畫よりの距離が映畫の 幅の 1.5 倍以下とすれば映畫の歪みが著しく目立つ樣になるを以て 1.5 倍以內には座席を設けざ る樣規定せり。(2)

猶映畫を餘りに近距離より見る時は，臨棜の不鮮明なる事見え過ぎ却て明瞭を缺くるのなり。 映䳆幕より次第に裳さかりて映畫の見易くなる距離を测りたるに，映畫の幅の凡そ 1.5 倍を得た り。故にての點より咉寫幕に最も近を座席は映畫の幅 ○ 1.5 倍以上たるてとを望む。

今簡單なる一例をとりて第二節に示す仰角の制限と 第五節に揭ぐる映寫幕に最も近を座席との關係を求め んとす。

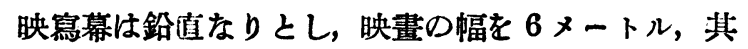
丈を 4.5 メートルとす。而して床面は水本なりとし， 映畫の下端より床面までの距離を 2 メートルとす。然 る時は眼の高さは床面上 1 メートルと假定せる故, 映 畫面の下端より眼の水平面までも亦 1 メートルとな る。

第六圖に於て，鎖線より上部は立面圖にして下部は 平面圖なりとす。 $A B$ を中心 $O$ を通る映畫の丈とす れば映畫の中心が $25^{\circ}$ の仰角をなす線は $O E$ となり $O E$ が床面 $F F$ より 2 メートルの高さにある水平面 と交る點 $E$ は郎ち最前列の觀容の眼の位置となるへしし 刃下部に於て $C D$ を映畫の幅とすれば, 映皃幕より その 1.5 倍の距離にある本面は $X X$ となる。乙の場

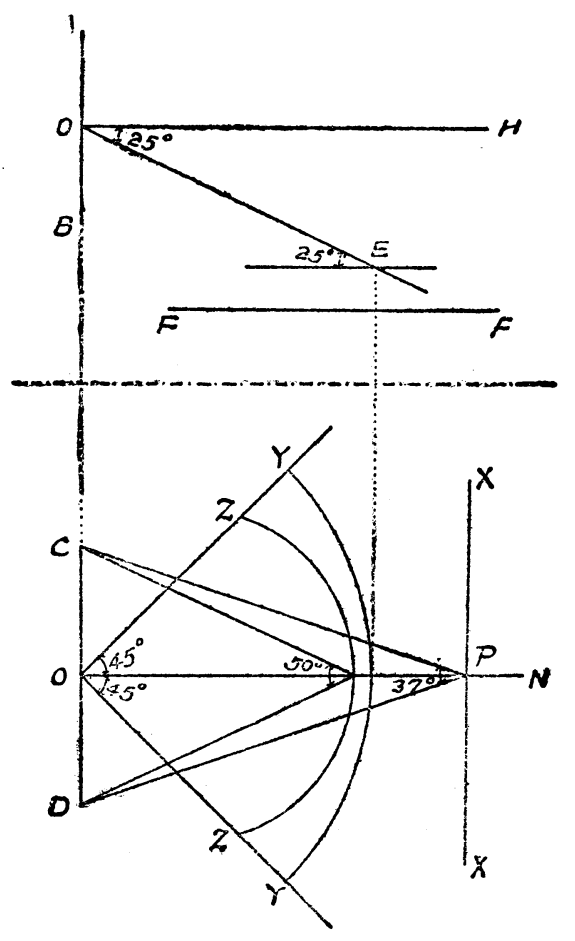

第 6 圆 
合映畫の幅の 1.5 倍による制限の方, 映畫の中心の仰角 $25^{\circ}$ の制限よりる安全となる。又映畫の 幅が $50^{\circ}$ を保つ如を點は $Z Z$ 線上に橫はり，映畫の中心 $O$ 老通る法線 $O^{\prime} N$ と $X$ との交點 $P$ を映畫の雨端 $C$ 及び $D$ と結オ゙付けたる二つの直線 $C P, D P$ のなす角は $37^{\circ}$ となる。

\section{第六節 睠棉幕より最も遠き座席に就て}

映畫より次第に遠ざかり行く時, 初めの間は距脑隹多少遠くとも映畫の觀覽に敢て不便を感ぜざ るも，逐には映畫を明睹に見ること能はざる至るへしし。普通の場合に距離裳をがために映畫の 見得ざるが如きてとなきも，今イギリスの例 (1) 几做ひ映棉幕より最も遠き座席の距離に制限を 設けたり。郎ち映畫の丈が視角 $5^{\circ}$ 以下となる如き距離に座席を設くるてとを禁じたり。視角 $5^{\circ}$ といふ代りにてれを距離を以ていふ時は映畫の丈の 12 倍とせり。（ての間には多少の相違あ bo)

以上述ぺしとてろにょり座席の配置を本面的に考ふれば，第七圖に示すが如をるのとなる。茲 机映畫の丈と幅との比を $3: 4$ と探りたり。

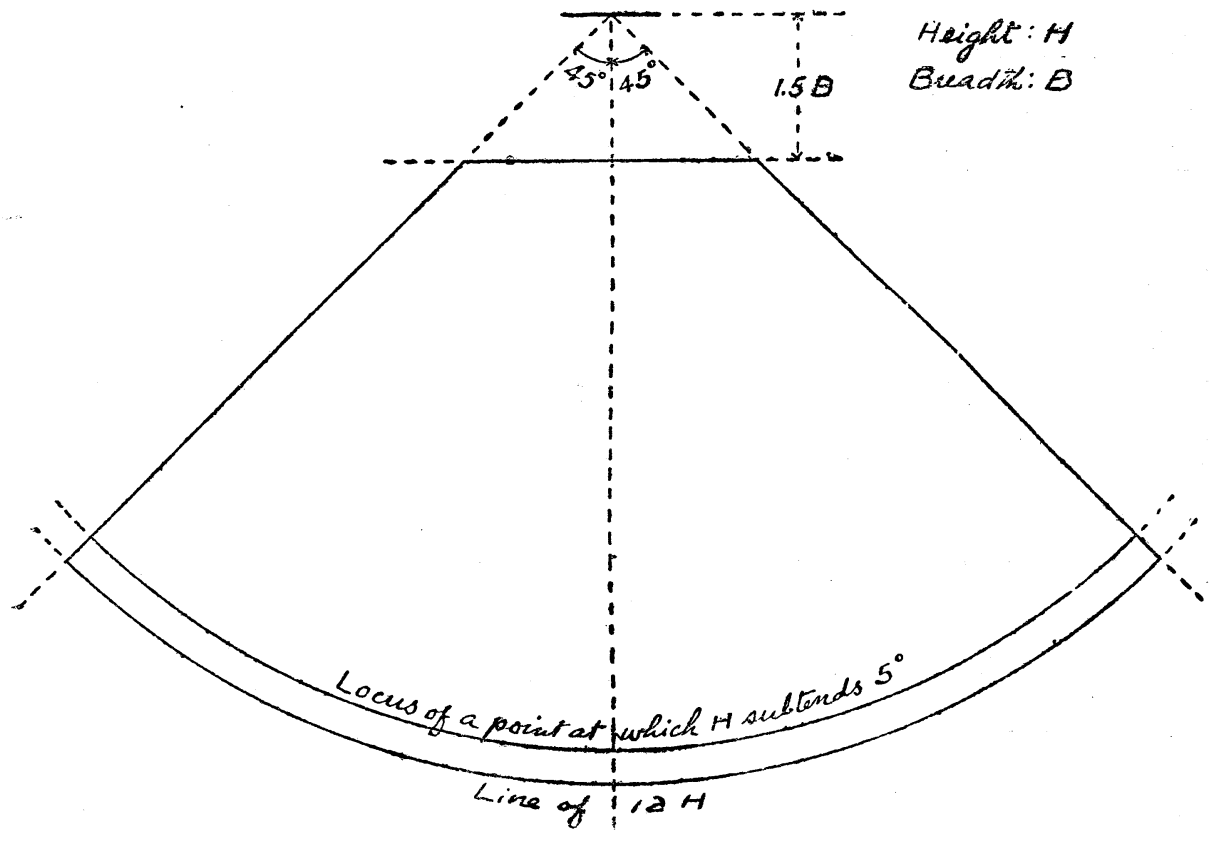

第 7 圖

\section{第七節 眼の疲勞の保護に就て}

フィルムに生したる傷のために映畫面にちらつをを生することは, 相當に眼の疲勞を來するの なり。然れども傷の大さ或は數を指定してその制限を設け, 又は使用時間に制限を設くるが如を ことは困難なり。殊に現在何等の資料なをため唯その必要を述ふるに止めたり。又觀覽時間の制 限に對しても資料なく，唯警視廳興行場及興業取綃規則 (5) 亿最長 4 時間考規定しあるを見る。

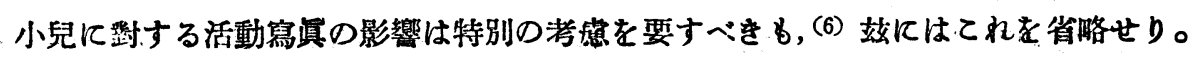




\section{第入節 映䆜幕の材料並に構造に就て}

凡そ光の物體に當り反射せらる〉時，その物體の表面の狀態により，反射せられたる光の有樣 は著しく異るものなり。今よく磨かれたる鏡面に細き一群の平行光線を斜に投する時は，所謂投 射角に等しを反射角をなしてその光は反射せらる」に反し，光澤なき粗面に光を投亦る時は，そ の光は各方向に擴散せらるなこと䠶に知られをるが如し。故に映寫幕の材料として鏡の如きもの を用ふる時は，單に反射光線の來る方向にある筧客のみ映畫を見得るものにして，他の觀客はて れを見ることを得す。然るに若し擴散度のよを吸墨紙の如をるのを用ふる時は，各方向の觀客は 殆ど同樣の明るさを以て映畫を見るてとを得るものなり。而して光の演散程度は各物質によりて

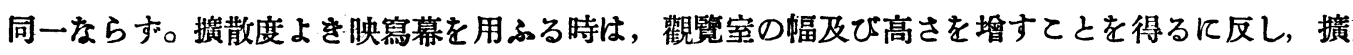
散度惡しきものを用ふる時は，室は細長をるのとせさるべからす。但し單に擴散度よき幕を用ひ たるの故を以て，室の幅を廣くし高さを增す時は，映畫に歪みを來たし，ての方より制限せらる ১を以て，唯單に摭散度のよを幕を用ふるといふよりは，その室の廣さに適したる撗散度を有す るもの১中にて最る反射率の高をるのを用ふる樣心䋰くるをよしとす。

\section{第九節 觀覽室照明に就て}

保安，風紀の上より㢣悓廳令興行場及興行取締規則 (5) に於ては, その第二章, 第四十一條に活 動寫㣀館の客席には映寫中之雖子觀客の容貌を認識し得べを照度を有する燈火の設備をなすへさ ことを規定し，更に觀客の使用し刃は來往する各場所には充分なる照度を有する電燈（電燈なを 土地に於ては安全と認むる他の燈火を以て代ふ）を設倩すべをてとを規定せり。之等の規定の如 何に拘らず普通觀覽席は映寫中と雖も其の暗黑となるが如き事なかるべも，その照度は映寫せ さる時に比しても，亦廊下その他の觀客の通行路に比しても著しく低かるへし。故に映寫に際し て一時に全部の燈火を消す時は, 眼はそれに應して急速に順應する樣作用せさるっがらす。又映 寫中は，室の內外に於て一般に可なりの照度の相違あるを以て映寫中に入場せんとする時は，單 に宾席に行くべき方向を認め得さるのみならす，比較的明るく點燈せられたる室外より室內に入 る時の急激なる變化のため, 眼汢その調節に非常なる苦痛を感するものなり。室內ょり室外に出 でんとナる場合も亦同樣なり。而して映寫中に於ける室內の照度に就ては, 燈火の配置を適當に

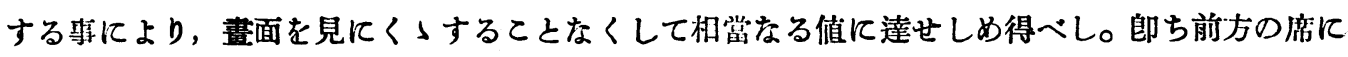
於ては幕面により反射せらるっ光によりて幾分照らさるっを以て，殆ど燈火の必要なく，且つ前 方に於ては燈火のために，畫の見え方の影響せらるつてと大なれば，燈火の照度は暗を必要あれ ども, 後方に於ては畫面に影響するてと少なければ, 前方に比して明るくすてとを得へく, 前方 より後方に淮むに從ひ次第に照度を增加せしめ得るが如し。かくの如くする時は後方より室內に 入り來る場合に眼の調䇫の上に利益あるぺし。(1)

\section{文献}

(1) Interim Report of the Joint Committee on Eye Strain in Cinemas. Appointed by the Illuminating Engineering Society, October, 1919)

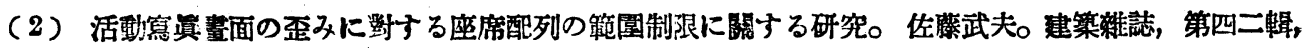


第五一一號，七○九頁，昭和三年，七月。

(3) Report of the Society of Motion Picture Engineers (U.S.A.)

(4) American Theatres of To-day.

(5) 與行場及興行取楴規則。警視聽合。

(6) La protection de d'enfant contre les dangers de cinématographe. G.Ichok. Revue d'Hygiène et de Médecine Prérentive. 49, 11, Noy. 1927.

(7) Diffusing Media-Projections and Focusing Screens. Report No. 8, I. E. S. Committee on Glare, 1914-15. Trans. Ill. Eng. Soc. 11, 92, 1916.

(8) Motion Picture Projection with Mazda Lamps. H.H. Magdsick and C. E. Egeler. Bulletin 33. B, National Lamp Works of General Electric Co. May. 20, 1924.

(9) Reflection Characteristics of Projection Screen. L.A. Jones and C. Tuttle. Trans' Soc. Mot. Pict. Eng. No. 28, 1927.

一般參考として

Deutsches Film- und Kinorecht. Dr. Ernst Eckstein.

外國より我が活動寫㗨照明委員會へ提出せられをる文献

$\boldsymbol{ア} ン$ カ合衆國

The Minimum Radiation Visually Perceptible. P. Reeres. Astrophys. J. 46, 167, 1917.

The Effect of Size of Stimulus on the Contrast Sensibility of the Retina. P. Reeres. J. Opt. Soc. Amer. 1, 148, 1917.

The Interior Illumination of the Motion-Picture Theatre. LA. Jones. Trans. Soc. Mot. Pict. Eng. No. 10, 83, 1920.

Diffusing Media-Projection and Focusing Screens Trans. I1l. Eng. Soc. 11, 92, 1916.

Reflection Characteristics of Projection Screens. L.A. Jones and C. Tuttle. Trans. Soc. Mot. Pict. Eng. No. 28, 183, 1927.

Printing Exposure and Density in Motion Picture Positives. L.A. Jones. Trans. Soc. Mot. Pict. Eng. No. 15, 102, 1922.

The Use of Color for the Embellishment of the Motion Picture Program. L.M. Townsend and L.A Jones. Trans. Soc. Mot. Pict. Eng. No. 38, 1925.

The Effect of Projection Lens Flare upons the Contrast of a Motion Picture Image. L.A. Jones and C. Tuttle. Trans. Soc. Mot. Pict. Eng. No 25, 153, 1926.

Tho Relation between the Specular and the Diffuse Photographic Densities. L. Silberstein and C. Tuttle. J. Opt. Soc. Amer. 14, 365, 1927.

Colour Vision and the Design of Kine' Theatres. K.C.D. Hickman. Phot. J. 65, 355, 1925.

Two Pamphlets on "Society of Motion Picture Engineers."

$$
1 \neq y \text { ス }
$$

Interim Report of the Joint Committee on Eye Strain in Cinemas. (Appointed by the Illuminating Engineering Society. October, 1919) 